\title{
ПОДГОТОВКА КИКБОКСЕРОВ И РЕЗУЛЬТАТЫ ВЫСТУПЛЕНИЯ НА РЕГИОНАЛЬНЫХ, ВСЕРОССИЙСКИХ И МЕЖДУНАРОДНЫХ ТУРНИРАХ
}

\section{PREPARATION OF KNOBBOXERS AS A BEGINNER TO THE FIRST INTERNATIONAL TOURNAMENT}

\section{A. Poteryakhin \\ I. Voronin \\ V. Kondakov}

Summary: The technique of training beginner kickboxers during eight years of classes before their first international tournament is considered. The methodology is based on the technical, tactical and physical preparation of athletes for the main start of the year.

Keywords: kickboxing, international tournament, physical training, technical and tactical training, beginner kickboxer.
Потеряхин Алексей Андреевич

ФГАОУ ВО «Белгородский государственный национальный исследовательский университет»

Kingmickey@mail.ru

Воронин Игорь Юрьевич

К.п.н., дочент, ФГАОУ ВО «Белгородский государственный национальный исследовательский университет» ivoronin@bsu.edu.ru

Кондаков Виктор Леонидович

Д.п.н., профессор, ФГАОУ ВО «Белгородский государственный национальный исследовательский университет»

kondakov@bsu.edu.ru

Аннотация: В данной статье рассмотрена методика подготовки начинающих кикбоксеров в течение восьми лет занятий. В основу методики взята техникотактическая и физическая подготовка спортсменов к главному старту года.

Ключевые слова: кикбоксинг, международный турнир, физическая подготовка, технико-тактическая подготовка, психологическая подготовка.

в каждом разделе кикбоксинга нужна совершенная техника, чтобы доказать своё превосходство над противником. А овладев техникой, скоростью и силой этих разделов, проблем в ринговых дисциплинах у спортсмена не будет, и он смело может заявлять о себе на крупных соревнованиях.

В исследовании были использованы следующие методы: анализ литературных источников; наблюдение тестирование; математико-статистические методы сбора, обработки и анализа данных.

Исследование проводилось на базе МБУДО БДДТ, МБОУ ЛИЦЕЙ №9, МБОУ СОШ № 21 г. Белгород в спортивном зале кикбоксинга. В качестве испытуемых выступали новички-кикбоксеры с 2011/12 по 2019/20 учебных годов.

Современная техника кикбоксинга многообразна. Для результативных занятий кикбоксингом в разных разделах необходимо постепенное освоение всего арсенала техники боя с установкой на дальнейшее применение наиболее эффективных приемов для конкретного этапа обучения.

Для эффективного овладения основной техники боя следует изучать в строгой последовательности: боевую стойку, передвижения в стойке, удары руками, удары но- 
гами, дистанцию в парах, финты, сложные удары.

Первый учебный год подразделяется на 5 этапов технико-тактической подготовки (табл. 1), в то же время физическая подготовка является неотъемлемой частью всей спортивной подготовки. Далее мы более подробно остановимся на технико-тактической подготовке. В начале занятий (1 этап сентябрь-октябрь) начинающие кикбоксеры изучают технику кикбоксинга. На 2-м этапе обучения (ноябрь-декабрь) изучается работа в парах и в завершении этого этапа проходят первые соревнования среди новичков. В январе-феврале основное внимание кикбоксеров направлено на технико-тактическую подготовку. Спортсменов на 3 этапе необходимо обратить на подготовку к всероссийским соревнованиям. Весной, на 4 и 5 этапе подготовки, основное время на учебно-тренировочных занятиях уделяется специальной физической подготовке.

Таблица 1

Начальные этапы обучения кикбоксеров

\begin{tabular}{|c|c|c|c|c|}
\hline \multicolumn{5}{|c|}{1 этап обучения } \\
\hline Месяц\Неделя & 1 неделя & 2 неделя & 3 неделя & 4 неделя \\
\hline Сентябрь & $\begin{array}{c}\text { Разминка (10\%) + фронт-кик } \\
\text { и прямой удар рукой (70\%) + } \\
\text { физическая подготовка (15\%)+ } \\
\text { заминка (5\%) }\end{array}$ & $\begin{array}{c}\text { Разминка (10\%) + раунд-кик } \\
\text { и боковой удар рукой }(70 \%)+ \\
\text { физическая подготовка }(15 \%)+ \\
\text { заминка }(5 \%)\end{array}$ & $\begin{array}{c}\text { Разминка (10\%) + сайт-кик и } \\
\text { удар рукой апперкот (70\%) + } \\
\text { физическая подготовка (15\%) + } \\
\text { заминка (5\%) }\end{array}$ & $\begin{array}{c}\text { Разминка (10\%) + хук-кик и } \\
\text { бэкфист }(70 \%)+\text { физическая под- } \\
\text { готовка }(15 \%)+\text { заминка }(5 \%)\end{array}$ \\
\hline Октябрь & $\begin{array}{c}\text { Разминка (10\%) + сложные } \\
\text { удары ногами с разворота (70\%) } \\
+ \text { физическая подготовка (15\%) + } \\
\text { заминка }(5 \%) \\
\end{array}$ & $\begin{array}{c}\text { Разминка }(10 \%)+\text { фехтующая } \\
\text { нога и обманные ноги }(70 \%)+ \\
\text { физическая подготовка (15\%) + } \\
\text { заминка (5\%) }\end{array}$ & $\begin{array}{c}\text { Разминка (10\%) + свобод- } \\
\text { ная работа руками }(70 \%)+ \\
\text { физическая подготовка }(15 \%)+ \\
\text { заминка }(5 \%) \\
\end{array}$ & $\begin{array}{c}\text { Разминка }(10 \%)+\text { свободная } \\
\text { работа руками и ногами }(70 \%)+ \\
\text { физическая подготовка }(15 \%)+ \\
\text { заминка }(5 \%) \\
\end{array}$ \\
\hline \multicolumn{5}{|c|}{2 этап обучения } \\
\hline Ноябрь & $\begin{array}{c}\text { Разминка (7\%) + лайт-контакт } \\
\text { - атака (83\%) + физическая под- } \\
\text { готовка (5\%) + заминка (5\%) }\end{array}$ & $\begin{array}{c}\text { Разминка }(7 \%)+\text { лайт-контакт } \\
\text { - встречная работа }(83 \%)+ \\
\text { физическая подготовка }(5 \%)+ \\
\text { заминка }(5 \%) \\
\end{array}$ & $\begin{array}{c}\text { Разминка }(7 \%)+\text { лайт-контакт } \\
\text { - работа от ноги (83\%) + } \\
\text { физическая подготовка (5\%)+ } \\
\text { заминка }(5 \%) \\
\end{array}$ & $\begin{array}{c}\text { Разминка (7\%) + лайт-контакт } \\
\text { - свободная работа (83\%) + } \\
\text { физическая подготовка }(5 \%)+ \\
\text { заминка (5\%) }\end{array}$ \\
\hline Декабрь & $\begin{array}{c}\text { Разминка (5\%) + лайт-контакт - } \\
18 \text { раундов }(90 \%)+\text { физическая } \\
\text { подготовка }(3 \%)+\text { заминка }(2 \%)\end{array}$ & $\begin{array}{c}\text { Разминка (10\%) + лайт- } \\
\text { контакт - } 12 \text { раундов }(60 \%)+ \\
\text { физическая подготовка }(20 \%)+ \\
\text { заминка }(10 \%) \\
\end{array}$ & $\begin{array}{c}\text { Разминка (20\%) + лайт- } \\
\text { контакт - 9 раундов }(45 \%)+ \\
\text { физическая подготовка (25\%)+ } \\
\text { заминка (10\%) } \\
\end{array}$ & $\begin{array}{c}\text { Разминка (30\%) + лайт- } \\
\text { контакт - 6 раундов (30\%) + } \\
\text { физическая подготовка }(30 \%)+ \\
\text { заминка }(10 \%) \\
\end{array}$ \\
\hline \multicolumn{5}{|c|}{3 этап обучения } \\
\hline Январь & $\begin{array}{c}\text { Разминка }(7 \%)+\text { поинтфайтинг } \\
\text { - атака }(83 \%)+\text { физическая под- } \\
\text { готовка (5\%) + заминка (5\%) }\end{array}$ & $\begin{array}{c}\text { Разминка (7\%) + поинтфайтинг } \\
\text { - встречная работа }(83 \%)+ \\
\text { физическая подготовка (5\%)+ } \\
\text { заминка (5\%) }\end{array}$ & $\begin{array}{c}\text { Разминка }(7 \%)+\text { поинтфай- } \\
\text { тинг - работа от ноги }(83 \%)+ \\
\text { физическая подготовка }(5 \%)+ \\
\text { заминка }(5 \%)\end{array}$ & $\begin{array}{c}\text { Разминка (7\%) + поинтфайтинг } \\
\text { - свободная работа (83\%) + } \\
\text { физическая подготовка (5\%) + } \\
\text { заминка (5\%) }\end{array}$ \\
\hline Февраль & $\begin{array}{c}\text { Разминка }(7 \%)+\text { stop and go - } \\
\text { атака + } \\
\text { встречная работа (83\%) + } \\
\text { физическая подготовка (5\%)+ } \\
\text { заминка (5\%) }\end{array}$ & $\begin{array}{c}\text { Разминка }(7 \%)+\text { финт ногой - } \\
\text { атака }+ \\
\text { встречная работа (83\%) + } \\
\text { физическая подготовка (5\%) + } \\
\text { заминка (5\%) }\end{array}$ & $\begin{array}{c}\text { Разминка (7\%) + выпад - } \\
\text { атака + } \\
\text { встречная работа (83\%) + } \\
\text { физическая подготовка (5\%) + } \\
\text { заминка (5\%) }\end{array}$ & $\begin{array}{c}\text { Разминка (7\%) + свободная } \\
\text { атака + } \\
\text { встречная работа (83\%) + } \\
\text { физическая подготовка (5\%)+ } \\
\text { заминка (5\%) }\end{array}$ \\
\hline \multicolumn{5}{|c|}{4 этап обучения } \\
\hline Март & $\begin{array}{c}\text { Разминка (10\%) + гантели (15\%) } \\
\text { + теннисные мячи (15\%) + } \\
\text { спарринги (35\%) + скакалка (15\%) } \\
\text { + заминка (10\%) }\end{array}$ & $\begin{array}{c}\text { Разминка (10\%) + резина (15\%) } \\
\text { + тяжелые мячи (15\%) + спар- } \\
\text { ринги (35\%) + скакалка (15\%) + } \\
\text { заминка (10\%) }\end{array}$ & $\begin{array}{c}\text { Разминка (10\%) + утяжелители } \\
(15 \%)+\text { боксерские мешки } \\
(15 \%)+\text { спарринги (35\%) + } \\
\text { скакалка (15\%) + заминка (10\%) }\end{array}$ & $\begin{array}{c}\text { Разминка (10\%) + Лестница } \\
(15 \%)+\text { боксерские лапы (15\%) } \\
+ \text { спарринги (35\%) + скакалка } \\
(15 \%)+\text { заминка 10\%) }\end{array}$ \\
\hline Апрель & $\begin{array}{c}\text { Бег (15\%) + разминка (10\%) + } \\
\text { тяжелые мячи }(15 \%)+\text { спарринги } \\
(35 \%)+\text { скакалка }(15 \%)+3 \text { - } \\
\text { минка }(10 \%)\end{array}$ & $\begin{array}{c}\text { Бег (15\%) + разминка (10\%) + } \\
\text { боксерские мешки (15\%) + спар- } \\
\text { ринги (35\%) + скакалка (15\%) + } \\
\text { заминка (10\%) }\end{array}$ & $\begin{array}{c}\text { Бег (15\%) + разминка }(10 \%)+ \\
\text { лестница (15\%) + 6оксерские } \\
\text { лапы }(15 \%)+\text { спарринги (35\%) } \\
+ \text { + заминка }(10 \%) \\
\end{array}$ & $\begin{array}{c}\text { Бег }(15 \%)+\text { разминка }(10 \%)+ \\
\text { резина }(15 \%)+\text { гантели }(15 \%) \\
+ \text { спарринги }(35 \%)+\text { заминка } \\
(10 \%)\end{array}$ \\
\hline \multicolumn{5}{|c|}{5 этап обучения } \\
\hline Май & $\begin{array}{c}\text { Разминка (10\%) + растяжка (30\%) } \\
\text { + статика } 5 \text { секунд * } 24 \text { раунда * } 4 \\
\text { удара (20\%) + спарринги (20\%) + } \\
\text { скакалка (10\%) + заминка (10\%) }\end{array}$ & $\begin{array}{c}\text { Разминка (10\%) + растяжка } \\
(30 \%)+\text { статика } 10 \text { секунд * } \\
12 \text { раундов * } 4 \text { удара (20\%) + } \\
\text { спарринги (20\%) + скакалка } \\
(10 \%)+\text { заминка (10\%) }\end{array}$ & $\begin{array}{c}\text { Разминка (10\%) + растяжка } \\
(30 \%)+\text { статика } 15 \text { секунд * } 8 \\
\text { раундов * } 4 \text { удара (20\%) + спар- } \\
\text { ринги (20\%) + скакалка (10\%)+ } \\
\text { заминка (10\%) }\end{array}$ & $\begin{array}{c}\text { Разминка (10\%) + растяжка } \\
(30 \%)+\text { статика } 20 \text { секунд *6 } \\
\text { раундов * } 4 \text { удара (20\%) + спар- } \\
\text { ринги (20\%) + скакалка (10\%)+ } \\
\text { заминка (10\%) }\end{array}$ \\
\hline
\end{tabular}


Далее, в июне, спортсмены уходят на отдых, который составляет 3 полные недели. По окончании отдыха со спортсменами согласовывается календарный план соревнований на следующий учебный год, определяется главный турнир года, как правило, международный старт и начинается подготовка к нему.

Важно обратить внимание на полученные результаты, представленные в таблице 2, первых соревнований среди новичков с 2011/12 по 2019/20 учебный год по представленной авторской методике подготовки.

Анализ данных, представленных в таблице 2 доказы- вает, что начинающие кикбоксеры успешно выступают на своих первых соревнованиях среди новичков с использованием в тренировочном процессе авторской методики подготовки. На первых соревнованиях для новичков за 8 учебных лет мы видим, что все спортсмены со 100\% вероятностью занимают призовые места. Из них 46\% занимают первые места, 35\% вторые места и 19\% третьи места.

Важно обратить внимание на полученные результаты, представленные в таблице 3, всероссийских соревнований с 2011/12 по 2019/20 учебный год по представленной авторской методике подготовки.

Таблица 2

Результаты первых соревнований среди новичков с 2011/12 по 2019/20 учебный год

\begin{tabular}{|c|c|c|c|c|c|}
\hline \multirow{2}{*}{$\begin{array}{c}\text { Уч.годІ } \\
\text { Результат }\end{array}$} & $\begin{array}{c}\text { Количество } \\
\text { чел. }\end{array}$ & \multicolumn{4}{|c|}{ Медали } \\
\cline { 3 - 6 } & 3олото & Серебро & Бронза & Итого \\
\hline $2011 / 12$ & 10 человек (100\%) & 6 медалей (60\%) & 4 медали (40\%) & - & 10 медалей (100\%) \\
\hline $2012 / 13$ & 23 человек (100\%) & 6 медалей (26\%) & 7 медалей (30\%) & 10 медалей (44\%) & 23 медали (100\%) \\
\hline $2013 / 14$ & 13 человек (100\%) & 6 медалей (46\%) & 7 медалей (54\%) & - & 13 медалей (100\%) \\
\hline $2014 / 15$ & 10 человек (100\%) & 5 медалей (50\%) & 5 медалей (50\%) & - & 10 медалей (100\%) \\
\hline $2015 / 16$ & 34 человека (100\%) & 19 медалей (56\%) & 10 медалей (29\%) & 5 медалей (15\%) & 34 медали (100\%) \\
\hline $2016 / 17$ & 22 человека (100\%) & 11 медалей (50\%) & 6 медалей (27\%) & 5 медалей (23\%) & 22 медали (100\%) \\
\hline $2017 / 18$ & 40 человек (100\%) & 18 медалей (45\%) & 13 медалей (35,5\%) & 9 медалей (22,5\%) & 40 медалей (100\%) \\
\hline $2018 / 19$ & 21 человек (100\%) & 9 медалей (43\%) & 8 медалей (38\%) & 4 медали (19\%) & 21 медаль (100\%) \\
\hline Итого: & $\mathbf{1 7 3}$ человека (100\%) & $\mathbf{8 0 ~ м е д а л е и ̆ ~ ( 4 6 \% ) ~}$ & $\mathbf{6 0 ~ м е д а л е и ̆ ~ ( 3 5 \% ) ~}$ & $\mathbf{3 3 ~ м е д а л и ~ ( 1 9 \% ) ~}$ & $\mathbf{1 7 3}$ медали (100\%) \\
\hline
\end{tabular}

Таблица 3

Результаты всероссийских соревнований с 2011/12 по 2018/19 учебный год

\begin{tabular}{|c|c|c|c|c|c|}
\hline \multirow{2}{*}{ Соревнования } & \multirow{2}{*}{$\begin{array}{c}\text { Количество } \\
\text { чел. }\end{array}$} & \multicolumn{4}{|c|}{ Медали } \\
\hline & & Золото & Серебро & Бронза & Итого \\
\hline Первенство ЦФ0 2012 & 4 человека (100\%) & 3 медали (75\%) & 2 медали (50\%) & 3 медали (75\%) & 8 медалей (200\%) \\
\hline Первенство России 2012 & 2 человека (100\%) & 1 медаль (50\%) & - & 1 медаль (50\%) & 2 медали (100\%) \\
\hline Первенство ЦФ0 2013 & 9 человек (100\%) & 4 медали (44,25\%) & 6 медалей (66,375\%) & 6 медалей (66,375\%) & 16 медалей (177\%) \\
\hline Кубок России 2013 & 6 человек (100\%) & - & - & 2 медали (33\%) & 2 медали (33\%) \\
\hline Первенство России 2013 & 1 человек (100\%) & 1 медаль (100\%) & - & - & 1 медаль (100\%) \\
\hline Первенство ЦФ0 2014 & 21 человек (100\%) & 17 медалей (80,75\%) & 17 медалей (80,75\%) & 18 медалей (85,5\%) & 52 медали (247\%) \\
\hline Кубок России 2014 & 2 человека (100\%) & 4 медали (200\%) & - & 1 медаль (50\%) & 5 медалей (250\%) \\
\hline Первенство России 2014 & 10 человек (100\%) & 1 медаль (10\%) & 5 медалей (50\%) & 1 медаль (10\%) & 7 медалей (70\%) \\
\hline Кубок России 2015 & 7 человек (100\%) & 1 медаль (14\%) & 4 медали (57\%) & 4 медали (57\%) & 9 медалей (128\%) \\
\hline Первенство России 2015 & 5 человек (100\%) & - & 2 медали (40\%) & 1 медаль (20\%) & 3 медали (60\%) \\
\hline Первенство ЦФ0 2016 & 20 человек (100\%) & 9 медалей (45\%) & 5 медалей (25\%) & 7 медалей (35\%) & 21 медаль (105\%) \\
\hline Первенство России 2016 & 16 человек (100\%) & 4 медали (25\%) & 6 медали (37\%) & 9 медалей (56\%) & 19 медалей (118\%) \\
\hline Первенство ЦФ0 2017 & 23 человека (100\%) & 13 медалей (56\%) & 5 медалей (22\%) & 4 медали (17\%) & 22 медали (95\%) \\
\hline Первенство России 2017 & 6 человек (100\%) & 2 медали $(33,5 \%)$ & 3 медали (49\%) & 2 медали (33,5\%) & 7 медалей (116\%) \\
\hline Кубок России 2018 & 10 человек (100\%) & 8 медалей (80\%) & 2 медали (20\%) & 4 медали (40\%) & 14 медалей (140\%) \\
\hline Первенство России 2018 & 12 человек (100\%) & 4 медали (33\%) & 6 медалей (50\%) & 4 медали (33\%) & 14 медалей (116\%) \\
\hline Первенство ЦФ0 2019 & 14 человек (100\%) & 13 медалей (93\%) & 7 медалей (50\%) & 8 медалей (57\%) & 28 медалей (200\%) \\
\hline Первенство России 2019 & 9 человек (100\%) & 9 медалей (100\%) & 8 медалей (89\%) & 2 медали (22\%) & 19 медалей (211\%) \\
\hline Кубок России 2019 & 1 человек (100\%) & - & 1 медаль (100\%) & - & 1 медаль (100\%) \\
\hline Итого за 8 лет: & 178 человек (100\%) & 94 медали (53\%) & 79 медалей (44\%) & 77 медалей (43\%) & 250 медалей (140\%) \\
\hline
\end{tabular}


Анализ данных, представленных в таблице 3 доказывает, что кикбоксеры успешно выступают на всероссийских соревнованиях с использованием в тренировочном процессе авторской методики подготовки. За 8 лет выездов на самые главные всероссийские соревнования года (первенство ЦФО, кубок России и первенство России) у спортсменов клуба есть шанс со $140 \%$ вариантностью вернуться домой с медалью. Из них 53\% с золотой медалью, 44\% с серебряной медалью и 43\% с бронзовой медалью.

Следует отметить, что результаты международных соревнований с 2011/12 по 2018/19 учебный год, представленных в таблице 4, подтверждают результаты успешной авторской методики подготовки, которая продолжается после 21-дневного отдыха в июне меся-

це, успешного согласования календарного плана соревнований, выбора международного турнира и анализа действующих победителей кубков и первенств Европы и Мира.

Результаты, представленные в таблице 4 указывают, что спортсмены, увеличивая физическую и технико-тактическую подготовку, успешно продолжают выступать на самых главных турнирах года. Это отражается на стабильном результате международных соревнований в течение 9 лет, где кикбоксеры уверенно одерживают победы у действующих победителей первенств и кубков Мира и Европы. У спортсменов клуба есть шанс вернуться с медалью 195\%. Из них 75\% вернуться победителем, 56\% стать финалистом данного турнира и 64\% призером международного старта. Выводы:

Таблица 4

Результаты международных соревнований с 2011/2012 по 2019/2020 учебный год

\begin{tabular}{|c|c|c|c|c|c|}
\hline \multirow{2}{*}{ Соревнования } & \multirow{2}{*}{$\begin{array}{l}\text { Количество } \\
\text { чел. }\end{array}$} & \multicolumn{4}{|c|}{ Медали } \\
\hline & & Золото & Cеребро & Бронза & Итого \\
\hline $\begin{array}{l}\text { Кубок Мира по Боевым } \\
\text { искусствам } 2012\end{array}$ & 4 человека (100\%) & 5 медалей (125\%) & 3 медали (75\%) & 1 медаль (25\%) & 9 медалей (225\%) \\
\hline Кубок Мира 2012 & 3 человека (100\%) & 1 медаль $(33,4 \%)$ & 1 медаль (33,3\%) & 1 медаль (33,3\%) & 3 медали (100\%) \\
\hline $\begin{array}{l}\text { Олимпиада Боевых } \\
\text { искусств } 2013\end{array}$ & 1 человек (100\%) & 1 медаль (100\%) & - & - & 1 медаль (100\%) \\
\hline $\begin{array}{l}\text { Олимпиада Боевых } \\
\text { искусств } 2014\end{array}$ & 12 человек (100\%) & 2 медали (16,5\%) & - & 6 медалей (49,5\%) & 8 медалей (66\%) \\
\hline Кубок Мира 2014 & 3 человека (100\%) & 2 медали (66,4\%) & 3 медали $(99,6 \%)$ & - & 5 медалей (166\%) \\
\hline Первенство Мира 2014 & 1 человек (100\%) & - & - & 1 медаль (100\%) & 1 медаль (100\%) \\
\hline Кубок Европы 2015 & 5 человек (100\%) & 3 медали (60\%) & 1 медаль (20\%) & 1 медаль (20\%) & 5 медалей (100\%) \\
\hline Первенство Европы 2015 & 1 человек (100\%) & - & - & 2 медали (200\%) & 2 медали (200\%) \\
\hline Кубок Мира 2015 & 10 человек (100\%) & 1 медаль (10\%) & 2 медали (20\%) & 6 медалей (60\%) & 9 медалей (90\%) \\
\hline $\begin{array}{l}\text { Кубок Балтийских } \\
\text { стран } 2015\end{array}$ & 4 человека (100\%) & 3 медали (75\%) & - & 1 медаль (25\%) & 4 медали (100\%) \\
\hline Первенство Мира 2016 & 1 человек (100\%) & - & 1 медаль (100\%) & - & 1 медаль (100\%) \\
\hline Кубок Европы 2017 & 4 человека (100\%) & 7 медалей (175\%) & 4 медали (100\%) & 3 медали (75\%) & 14 медалей (350\%) \\
\hline Кубок Мира 2017 & 5 человек (100\%) & 7 медалей (140\%) & 2 медали (40\%) & 3 медали (60\%) & 12 медалей (240\%) \\
\hline Первенство Европы 2017 & 1 человек (100\%) & - & 1 медаль (100\%) & - & 1 медаль (100\%) \\
\hline Мировой турнир 2018 & 4 человека (100\%) & 6 медалей (150\%) & 8 медалей (200\%) & 2 медали (50\%) & 16 медалей (400\%) \\
\hline Кубок Мира 2018 & 5 человек (100\%) & 2 медали (40\%) & 4 медали (80\%) & 6 медалей (120\%) & 12 медалей (240\%) \\
\hline $\begin{array}{l}\text { Евразийские игры Боевых } \\
\text { Искусств } 2018\end{array}$ & 5 человек (100\%) & 3 медали (60\%) & 4 медали (80\%) & 3 медали (60\%) & 10 медалей (200\%) \\
\hline Кубок Мира 2019 & 1 человек (100\%) & 3 медали (300\%) & 2 медали (200\%) & 2 медали (200\%) & 7 медалей (700\%) \\
\hline $\begin{array}{l}\text { Чемпионат Мира по } \\
\text { Боевым Искусствам } 2019\end{array}$ & 1 человек (100\%) & 2 медали (200\%) & - & - & 2 медали (200\%) \\
\hline $\begin{array}{l}\text { Международный } \\
\text { Гран-При } 2019\end{array}$ & 2 человека (100\%) & 5 медалей (250\%) & - & 3 медали (150\%) & 8 медалей (400\%) \\
\hline Кубок Европы 2020 & 4 человека (100\%) & 3 медали (75\%) & 5 медалей (125\%) & 8 медалей (200\%) & 16 медалей (400\%) \\
\hline Кубок Мира 2020 & 2 человека (100\%) & 3 медали (150\%) & 3 медали (150\%) & 2 медали (100\%) & 8 медалей (400\%) \\
\hline Итого за 9 лет: & 79 человек (100\%) & 59 медалей (75\%) & 44 медали (56\%) & 51 медаль (64\%) & 154 медали (195\%) \\
\hline
\end{tabular}




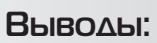

1. Разработанная методика подготовки спортсмена к первым соревнованиям среди новичков включала два разнонаправленных, но взаимодополняющих учебно-тренировочных сбора направленных на повышение технической подготовки спортсмена.

2. Технико-тактическая подготовка в тренировке спортсменов к всероссийским стартам имеет приоритетное направление в учебно-тренировочном процессе начинающих кикбоксеров. Одним из основных, в этой связи, является выявление «проблемных» зон подготовки кикбоксера и целенаправленное воздействие на них, позволяет не только улучшить его техническую подготовку, но и психологическое состояние.

3. Физическая подготовка в тренировке спортсменов к международным стартам имеет также приоритетное направление в учебно-тренировочном процессе. Одним из основных, в этой связи, является выявление «проблемных» зон подготовки кикбоксера и целенаправленное воздействие на них, позволяет не только улучшить его функциональное состояние, но и значительно повысить результативность соревновательной деятельности.

4. Определение недостаточной функциональной подготовки при нанесении прямых ударов предопределило необходимость использования в индивидуализированном тренировочном процессе кикбоксера гантелей, эспандера лыжника с 4 резинами и утяжелителей, которые применялись постоянно, за исключением двухнедельного цикла перед началом ответственных соревнований.
5. Результаты выступления на всероссийских и международных турнирах с 2012 по 2020 год показали успешность разработанной авторской программы подготовки, что выразилось в воспитании 26 победителей первенства ЦФО, 11 победителей кубка России, 14 победителей первенства России, 2 победителя Всероссийских игр Боевых Искусств, 3 победителей кубка Балтийских стран, 2 победителей Евразийских Боевых Искусств, 2 победителей Олимпиады Боевых Искусств, 2 победителей кубка Мира по Боевым Искусствам, 1 победителя Чемпионата Мира по Боевым искусствам, 2 победителей международного Гран-При, 4 победителей Мирового турнира, 10 победителей кубка Европы, серебряного призера и бронзового первенства Европы, 9 победителей кубка Мира, серебряного и бронзового призера первенства Мира в возрасте с 7 до 18 лет. А самый главный результат был показан на кубке Мира 2018 года в г. Римини (Италия), где Ксения Артебякина в 15 лет с весом 46 кг вошла В состав юниорской сборной России (16-18 лет, 50 кг), выиграла кубок Мира в возрастной группе 16-18 лет в весовой категории 50 кг и выполнила норматив Мастера Спорта России, а так же на кубке Мира 2020 года в г. Дублин (Ирландия), где Арина Кирик в 13 лет с весом 46 кг стала серебряным призером кубка Мира в возрастной группе 16-18 лет в весовой категории 50 кг и выполнила норматив Мастера Спорта России.

Таким образом, увеличение нагрузки позволяет с успехом выступать на международных стартах.

\section{ЛИТЕРАТУРА}

1. Потеряхин, А.А. Кикбоксинг. Татами-дисциплины: учебно-методическое пособие / А.А. Потеряхин, В.Л. Кондаков, И.Ю. Воронин. - Белгород : 000 «Эпицентр», 2020. - 160 с..

2. Потеряхин, А.А. Кикбоксинг. Техника для начинающих спортсменов : учеб.-метод. пособие / И.Ю. Воронин, А.А. Потеряхин. - Белгород: 000 «Эпицентр», 2018. $-56 \mathrm{c}$.

3. Потеряхин, А.А. Кикбоксинг. Лайт-контакт. Учебно-методическое пособие / И.Ю. Воронин, А.А. Потеряхин, - Белгород : 000 «Эпицентр», 2018. - 56 с.

4. Потеряхин, А.А. Кикбоксинг. Поинтфайтинг. Учебно-методическое пособие / И.Ю. Воронин, А.А. Потеряхин, - Белгород : 000 «Эпицентр», 2018. - 56 с.

5. Потеряхин, А.А. Кикбоксинг. Кик-лайт. Учебно-методическое пособие / И.Ю. Воронин, А.А. Потеряхин, - Белгород : 000 «Эпицентр», 2018. - 44 с.

6. Потеряхин, А.А. Кикбоксинг. Ближний бой и физическая подготовка. Учебно-методическое пособие / И.Ю. Воронин, А.А. Потеряхин, - Белгород : 000 «Эпицентр», 2018. - 64 с.

7. Иванов А.Л Кикбоксинг [Текст] / А.Л. Иванов. - Киев: Книга-Сервис, Перун, 1995. - 312 с.

8. Клещев, В.Н. Кикбоксинг. Учебник для вузов [Текст] / В.Н. Клещев. - М.: Академический проект, 2006 -228 c.

9. Ashley, S. Kickboxing [Текст] / S. Ashley. - England: Lumina Press, 2011. - 139 p.

10. Falsoni, E. Kickboxing the phenomenology of a sport [Текст] / E. Falsoni, A. Micheli. - Milan: miolagrafiche s.r.l. 2011. - 205 p.

(с) Потеряхин Алексей Андреевич (Kingmickey@mail.ru), Воронин Игорь Юрьевич (ivoronin@bsu.edu.ru), Кондаков Виктор Леонидович (kondakov@bsu.edu.ru).

Журнал «Современная наука: актуальные проблемы теории и практики» 